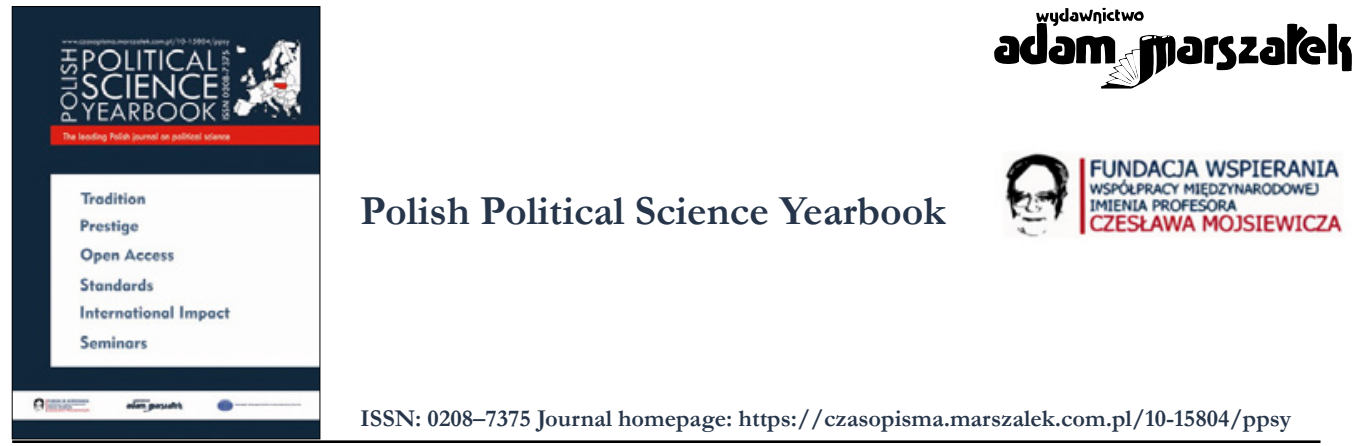

\title{
Protocooperation as a Model for the Russia-UAE Partnership
}

\author{
Andrzej Jacuch \\ ORCID: 0000-0003-1013-6107
}

To cite this article please include the following information:

- Journal title: Polish Political Science Yearbook

- Volume number: 50

- Year of publication: 2021

- Published ahead-of-print

Example styles:

[APA Style]: Jacuch, A. (2021). Protocooperation as a Model for the Russia-UAE Partnership. Polish Political Science Yearbook, 50(issue number), pages. https://doi.org/10.15804/ppsy202137

[Chicago Style]: Andrzej Jacuch, "Protocooperation as a Model for the Russia-UAE Partnership" Polish Political Science Yearbook 50, no. [issue number] (2021).

To link to this article: https://doi.org/10.15804/ppsy202137

Published ahead-of-print

\begin{tabular}{l} 
Fublished online: $\quad$ 10 July 2021 \\
\hline Printed issue: $\quad$ December 2021 \\
\hline Submit your article to PPSY
\end{tabular}




\author{
Andrzej Jacuch \\ Military University of Technology (Poland) \\ ORCID: 0000-0003-1013-6107 \\ e-mail: andrzej.jacuch@wat.edu.pl
}

\title{
Protocooperation as a Model for the Russia-UAE Partnership
}

\begin{abstract}
Russia's intervention in Syria in 2015 marked the Russian Federation (RF) return as a key player in the Middle East and North Africa. In this context, the relations between Russia and the UAE are of utmost importance for both entities, for the region, and globally. This article seeks to fill a gap in scholarly knowledge by answering questions about the nature of the emerging cooperation between Russia and the UAE. How Russia seeks to use the UAE to expand its sphere of influence in the MENA region and how the UAE uses this cooperation to achieve its foreign policy goals. The article applies protocooperation (an analogy to the ecological relationship) as a model for the Russia-UAE partnership. The RF is strengthening its position in the MENA regarding the UAE as a key partner for regaining its political, economic, and military influence in the MENA region. Russia-UAE's partnership aims at achieving conjunctural geopolitical interests benefiting from diminished Western, mainly the US, presence in the region.
\end{abstract}

Keywords: Russia, UAE, geopolitics, international relations, economy

\section{Introduction}

The Persian Gulf is a strategically important region for the entire world. On the Persian Gulf, there are located: UAE, Saudi Arabia, Qatar, Bahrain, Kuwait, Iraq, and Iran. The Russian Federation (RF), taking advantage of the reduced US presence in the region and the diminished US influence, maintains friendly relations with all the Persian Gulf states through political maneuvering. The Russian Federation has always been interested in this region, and after a short period associated with the collapse of the Soviet Union, it has been building its sphere of influence anew. The Arab Spring and the war in Syria have provided Russia with an opportunity to increase its involvement in the region and rebuild its influence, demonstrated by a revival in Russian economic and political activity throughout the region. Since 
2005, a new Russian approach to the Middle East has emerged, emphasizing transactional economic, propaganda, and ideological gains with a wide range of partners (Wasser, 2019, p. 1). Russia's intervention in Syria in 2015 marked the return of the RF as a key player in the Middle East and North Africa (MENA). In this context, the relations between Russia and the UAE are of utmost importance for both entities, the region, and globally. This article seeks to fill a gap in scholarly knowledge by answering questions about the nature of the emerging cooperation between Russia and the UAE. How Russia seeks to use the UAE to expand its sphere of influence in the MENA region and how the UAE uses this cooperation to achieve its foreign policy goals.

Much of the scholarly work on Russia-UAE relations to date has focused on a country or region-specific Moscow's "friendly" interactions with the UAE and warns about Russia's growing influence in the region (Ramani, 2020, pp. 125-140). Sim regards strategic partnership between Russia and the United Arab Emirates, robust growth in non-oil trade, direct investments, joint ventures, and alignment of perspectives over Syria, Libya, and stand against "all forms of terrorism and religious extremism" (Sim, 2018a, p. 48; 2019 and 2020). Rodin (2019,pp. 53-59) explores bilateral and multilateral international cooperation between Russia and the UAE, focusing on the implementation of cooperation in the field of high technology. Issaev and Kozhanov (2021) analyze the interaction between Russia and the Gulf Cooperation Council (GCC) countries, particularly with the UAE, based on pragmatism and overlapping interests.

In the following paragraphs, I seek to explain that Russia-UAE bilateral relations have a protocooperative nature. I use the analogy of protocooperation, an ecological relationship that can be established by species interactions, to describe the relationship between Russia and the United Arab Emirates. I study international cooperation, trade, and economic relations between the RF and the UAE through a protocooperative lens.

Investigating Russia-UAE relations, I intuitively apply the term of protocooperation, which originated from biology and is a type of ecological interaction where both the species involved in the interaction are benefitted, but the interaction is not obligatory. Huggett distinguishes four types of interaction between populations or species that favor peaceful coexistence - neutralism, protocooperation, mutualism, and commensalism. Protocooperation involves both populations benefiting one another in some way from their interaction (Huggett, 2004,pp. 187-188,215). Wan utilizes the analogy of cooperative or competitive interactions between populations within an ecosystem (protocooperation, mutualism, commensalism, competition, amensalism, and predation) to various types of international relationships. He refers to protocooperation as non-obligatory mutual gains between two populations (Wan, 2016, p. 4). Tshikantwa et al. (2018) use protocooperation (synergism) in microbiology. The terms protocooperation and protocooperative have also been used as adjectives in social psychology (Cikara \& Paluck, 2013, pp. 559-571), in the economy (Bateman, 2015), or when investigating social networks (Duarte, 2013, pp. 100-115), etc. 
This article aims to describe the UAE and Russia as a protocooperative partnership. For the sake of the analysis, I define protocooperation as optional interactions between the two countries in which there is an advantage for both. Whereas I use protocooperative partnership to describe the two countries cooperate in developing mutually beneficial win-win relationships.

The article is organized to answer: What is Russia's security concept for the Persian Gulf area? What is the framework for Russia-UAE cooperation? How do the strategic interests of the RF and the UAE coincide? What is the character of the partnership between the RF and the United Arab Emirates?

The article examines the Russian security concept for the Persian Gulf area and its diplomatic, trade, and economic actions that have made Russia a growing and vital force in the region. However, it also finds that Russia-UAE relations are based on specific mutually beneficial objectives for both of them. These relations might not be permanent and are rather protocooperative in nature as these two entities interact beneficially, though they may act individually.

For this research, initially, it was analyzed the literature of foreign policy, diplomacy, academia's and public opinions, related topics, and subsequent discussions and interviews with political science and military experts.

The article proceeds by first providing background on the Russian security concept for the Persian Gulf, the framework for Russia-UAE cooperation, followed with Russian tactics to influence the UAE and the region, analysis of strategic interests of the RF and the UAE, and summarizing on protocooperative character of the partnership between the RF and the UAE.

The study was conducted using time, subject, and source limiters. The article deals with the international relations of the RF and the UAE mostly in recent years. The high dynamics of international relations in the MENA region, the multifaceted nature, and the vastness of the subject matter are the reasons for limiting the analysis to the most significant components of Russia - UAE relations and their impact in the region. The article presents selected regional relations specific to the presented subject matter without considering regional relations with other actors of the international system active in the region, such as China or CIS ${ }^{1}$-UAE relations (Russian and CIS, 2020) and others. Available scientific research results on the relations between the UAE and Russia are somewhat limited. The paper relies mainly on the available English-language and Russian-language literature. Despite the limitations, the presented work may provide material for further research and discussion on Russia-UAE relations.

\footnotetext{
1 The Commonwealth of Independent States.
} 


\section{Russian Security Concept for the Persian Gulf Area}

The RF's 2015 National Security Strategy identifies Russia's ability to distinguish itself on the international stage as "[...] one of the world's leading powers" as a key strategic priority. Accordingly, the RF conducts its multi-vectoral foreign policy to achieve this goal. Russia's foreign policy is based on specific determinants that the World Order cannot be formed in isolation from the Middle East, and the main reason is its geostrategic location as a center of balance of power (Bani \& Mashagbeh, 2018, p. 28). The Foreign Policy Concepts of the Russian Federation $(2000,2013,2016)$ assert that Russia will work to stabilize the situation in the Middle East, expand bilateral relations, building multilateral dialogue at the ministerial meetings of the Russian-Arab Cooperation Forum, and continue strategic dialogue with the Cooperation Council for the Arab States of the Persian Gulf. The Concepts list the strategic dialogue with the GCC countries as a key priority.

Issaev and Kozhanov (2021) explain Russia's foreign policy toward the GCC as a bargaining strategy through diplomatic and political initiatives and using its presence in the key regional conflicts. Surkov (2021) stresses that the RF is re-establishing itself as one of the major external players in the Middle East. Russia considers Saudi Arabia and the Gulf monarchies to be the key power brokers in the Arab world. Its multi-vector Middle East policy orientation includes the protection of sovereignty, economic gain (oil, gas, and the arms trade), and expanding the Russian influence in the Western-dominated region (Sutyagin, 2017,pp. 106-109). Through its policy on the events in the Middle East, Russia is trying not to interfere directly in the affairs of those countries to gain the greatest respect and credibility to preserve the pace of peace and security desired. Furthermore, Russia has been aiming at preserving its areas of influence from aggression (Bani \& Mashagbeh, 2018, pp. 28-31). Stepanova (2018, pp. 35-57) discussed Russia's foreign policy in the Middle East as a "holistic alliance" with every country in the Middle East.

In 2019, the RF presented its concept for ensuring security in the Persian Gulf, evolving from previous Russian strategies. The concept presents ideas on how to stabilize the Persian Gulf region. The main principles listed in the concept are incrementalism, multilateralism, and strict observance of international law. The RF Ministry of Foreign Affairs describes the document as creating a holistic mechanism of collective security in the region and cooperation among all the states in the region on an equal basis (Presentation, 2019). The concept includes such priorities as a counter-terrorism coalition, a comprehensive security system in the Gulf area, the settlement of the Iraqi, Yemeni and Syrian crises, and the implementation of all agreements reached on the Iranian nuclear program. Among multilateral fora to act on the Gulf area's future security and cooperation system are the League of Arab States, the Organization of the Islamic Conference, and the Cooperation Council for the Arab States of the Gulf.

The RF concept emphasizes that the security system should be universal and comprehensive. It refers to a set of security, confidence-building, and control measures, us- 
ing geostrategic phraseology such as the non-use or threat of force in resolving disputes; mutual commitments to military transparency; arms control agreements; a WMD-free zone; agreements to combat international terrorism; and downsizing the international military presence in the region. The long-term objective is the creation of a security and cooperation organization in the Persian Gulf (PGSCO) that would include, in addition to the Gulf countries, Russia, China, the US, the EU, India, and other stakeholders as observers or associated members. In future, in the context of the Arab-Israeli settlement, the PGSCO could become an element of the regional security system for the Middle East and North Africa (Российская Концепция, 2019).

At Valdai, Foreign Minister Sergey Lavrov (2021) presented the concept as a multilateral platform to foster dialogue across the Gulf, clarifying further that this concept would be "akin to the Helsinki Process" and ensuring the region will evolve toward "a balance of interests and not become a territory of conflicts among major players once again".

Russia's approach is to maintain friendly relations with all the Gulf countries without exception and advance interaction with them based on equality and mutual respect. Has this approach been successful in the GCC? After 2015, at the regional level, Russia succeeded in achieving a balance in the Persian Gulf. It strengthened its alliance with Iran while establishing excellent relations with Saudi Arabia and the UAE. In 2017, the Middle East accounted for the largest share of Russian arms exports. The RF skillfully moves between regional powers with opposing interests: Israel and Iran, Saudi Arabia and Qatar, or Iran and Saudi Arabia. Its efficient diplomacy has made Russia an indispensable force in the region (Popescu \& Secrieru, 2018, p. 6).

The RF diplomatic initiative may appear as the symbol of Russia's successful positioning in the region. However, this view ignores Russia's economic limitations. The RF maintains a dialogue with all actors in the Middle East, focusing on areas of common interest, which ensures that it has no enemy in the region. However, such a strategy also makes it difficult to form any close alliance. It hinders the full ability to make progress on key issues, such as rebuilding Syria. Russia presents itself as a more influential and relevant power than it is. Pushing forward a non-hegemonic arrangement helps Moscow paint US sanctions ${ }^{2}$ as a contrasting symbol of American unilateralism and overreach (Czerny, 2021).

\section{The Framework for Russia-UAE Cooperation}

On December 8, 1971, six days after its creation, the UAE established diplomatic relations with the former Soviet Union (USSR). In 1991, the UAE recognized the Russian Federation as the successor state to the USSR. In 2007. UAE and the Russian Federation concluded a ten-year partnership agreement. In the following years, there were official visits by UAE authorities to Moscow. In 2017. The UAE and the Russian Federation strengthened bilateral

\footnotetext{
2 The Caesar Act.
} 
relations by approving a "statement of intent" to further shape diplomatic relations within the framework of the strategic partnership between the two countries. In June 2018, the two countries signed a "Declaration on Strategic Partnership" (Diplomatic success, 2019).

In October 2019, Russian President Vladimir Putin visited Abu Dhabi. The visit strengthened bilateral ties with the UAE, including cultural, academic, commercial, and economic ties (agreements worth $\$ 1.3$ billion) in the development of artificial intelligence, energy and telecommunications cooperation, and the Emirate's purchase of Russian aircraft and helicopters. As the positions of the Russian Federation and the UAE in the region converge, the countries have declared cooperation within the framework of a strategic partnership (Russia's Putin signs, 2019). The countries share regional interests, including maintaining coordination on key global and regional issues, most notably Syria, Libya, Yemen, and the Gulf situation (Fenton-Harvey, 2019).

The Russian Federation conducts multidirectional activities through foreign policy, multipolar ideologies, the Russian media, trade ties, and cooperation in regional security.

The overarching strategic visions of the RF and the UAE regarding security in the Gulf differ. In contrast, shared ideas about preserving stability in the region provide a source of coherence. These ideological synergies include shared opposition to a pre-emptive military strike on Iran and a desire for a multipolar commitment to Gulf security and overlap with shared geopolitical interests. It makes Gulf security a pillar of the strategic partnership between Russia and the UAE.

The aspirations of the Russian Federation and the UAE to address collective security challenges in the Gulf through multipolar engagement further strengthen the ideological partnership between the two states. Since the final stages of the Cold War, multipolarity has been a central tenet of Russian foreign policy. This concept allows non-Western powers to challenge US hegemony and is based on multilateral consensus decision-making.

The UAE is pursuing a multipolar approach to security in the region as it cooperates with the RF on the one hand and is an integral member of the US-backed Middle East Strategic Alliance on the other. The UAE recognizes that the RF deserves a seat at the table on collective security issues due to its status as a major non-Western power engaged in crisis diplomacy in the Middle East. Sim argues that the UAE has become involved in Russia's Gulf security plan because it "seeks to cooperate with the Russian Federation in de-escalating regional conflicts and wishes to build on the Russian Federation's successful diplomatic approach in the Middle East to date" (Ramani, 2020, pp. 125-140).

The Russian Federation interacts with the UAE through such instruments as the RussiaArab Business Council (RABC) and the Russia Business Council Dubai (RBC-Dubai). The $\mathrm{RABC}$ organization was founded by Yevgeny Primakov, whose vision for the MENA region was created as part of a soft power influence on the UAE authorities and other countries in the region. Yevgeny Primakov is the main exponent of the Russian vision of multipolarity on the world stage. The RBC is active in Dubai and contributes to the positive assessment of the RF's concept of multipolarity in the UAE (Karasik, 2017). Support for the RABC and 
RBC-Dubai comes from various sources, including the respective Russian embassies and local Russian expatriates.

The RF's trade and economic relations with the UAE are better off than with the other GCC countries. The UAE is the first Arab destination for Russian investment, with a contribution rate of over $90 \%$ of their total investment in Arab countries, while the foreign direct investment balance between the two countries was over 1.5. billions of dollars, $75 \%$ of which are Russian investments in the UAE, mainly in the real estate, wholesale and retail trade, industrial sector, and the communications and information technology sector (UAE is the first, 2021). The UAE is also the largest Gulf investor in Russia, with investments in infrastructure, petrochemicals, ports, aviation, real estate, telecommunications, information technology, healthcare, energy, oil, and gas (UAE is the first, 2021).

According to the Observatory of Economic Complexity (OEC) and data from the UN COMTRADE in 2019, Russia exported $\$ 2.47$ billion worth of products to the Emirates. The main products Russia exported to the United Arab Emirates are paintings, diamonds, and gold. The main services provided by Russia were transportation and computer and information services. In 2019, United Arab Emirates exported \$628 million worth of products to Russia. The main products were aircraft parts, instructional models, and rolled tobacco (Trade, 2021).

In 2020, despite the coronavirus pandemic, the value of trade between the UAE and Russia increased (Tariq, 2019). The UAE has become the second (after Egypt and before Israel) trading Russia's partner in the Middle East and accounts for $20 \%$ of Russia's trade with Arab countries combined (Rodkiewicz, 2021). The UAE is the largest Russia's trading partner in the Gulf region, with turnover totaled in 2020 to 3.27 billion dollars, accounting for $55 \%$ of all trade between Russia and the Persian Gulf (UAE is the first, 2021).

The UAE's state-owned Mubadala Investment Company has been leading investments into Russia since 2013. In 2018, it had acquired a 44 percent stake in an oil subsidiary of Gazprom. In cooperation with the Russian Fund for Direct Investment (RDIF), the company also established a joint venture with Gazprom to develop oil fields in Western Siberia. Mubadala Petroleum's investments in the Russian oil sector have exceeded \$300 million (Scaria, 2019). Reciprocally, in 2019, the UAE National Oil Company (ADNOC) awarded Lukoil a 5\% share in the Ghasha concession, which includes gas fields offshore Abu Dhabi. It is the first time that a Russian company has joined an ADNOC concession. The ADNOC also signed a strategic framework agreement with Gazprom Neft on upstream, downstream, and technology cooperation, including Abu Dhabi's exploration and production concessions, sour gas, enhanced oil recovery, and new technology, including artificial intelligence. The Rosatom signed an MOU with the UAE Atomic Energy Corporation on cooperation on nuclear energy (Griffin, 2019). The consortium of the Mubadala and the RDIF took a 22.5 percent stake in the largest chain of fitness clubs in Russia (Scaria, 2019). In June 2018, Russia opened its first Russian Centre for Digital Innovators and Information and Communication Technologies in Dubai’s Internet City (Scaria, 2019). 
In 2019, the RF and the UAE agreed on shared investments worth over $\$ 1.3 \mathrm{bn}$ - notably in the energy, advanced technology, and health sectors (Russia’s Putin signs, 2019). The strategic agreement between the Mubadala and SberBank of Russia will further boost the UAE-Russia cooperation in investments. They have further joint plans for various sectors, such as banking, health, water and electricity, and agriculture (Tariq, 2019). Moreover, in 2020, a pilot partnership between UAE University (UAEU) and the Gamaleya Research Institute of Epidemiology and Microbiology was announced (Tariq, 2019).

Additionally, there is a significant presence of Russians and Russian companies in the UAE. In 2018 more than 1.8 million Russian tourists stayed in the UAE hotels (Scaria, 2019). In 2019, 800,000 Russian tourists visited the UAE, and 17,000 Russian citizens resided in the UAE. Moreover, 3,000 Russian companies are currently operating in the UAE (Tariq, 2019).

The UAE has also become the only major regional customer for Russian arms. However, the RF remains a marginal supplier. According to SIPRI, only about $5 \%$ of arms imports in 2016-2020 came from Russia. In 2019, UAE purchased \$710 million of anti-tank weapons from Russia (“UAE buys $\$ 5 \mathrm{bn}$ of weapons during four-day arms exhibition”, 2017). Other plans include Sukhoi fighters and a joint light combat fighter jet project.

The assessment of the dynamic and development trends of trade and economic ties between the RF and the UAE indicates they continue to advance. In the last years, the qualitative evolution of Russia's relations with the UAE is deepening. There is a shift in the enhancement of cooperation, including in the field of investments. Both countries have been cooperating in science, health, banking, water, and food security, technology (especially Artificial Intelligence), oil and gas, and many other fields. Russia's United Aircraft Corporation and Mubadala will establish a joint venture to develop a supersonic passenger plane (Bailey, 2021). Further cooperation will develop most notably in energy, banking, science, innovation, space discovery, culture, health and technology, and food security, which is a priority for the UAE (Tariq, 2019). Russia is also looking to increase agricultural and industrial exports to the UAE (Seban Scaria, 2019).

The Russian war doctrine recognizes the information struggle as a key element of modern military action, and Russia has been developing capabilities in this area (Darczewska, 2015, pp. 9-15). In 2013, the Chief of General Staff of the Russian Armed Forces General Valeri V. Gerasimov wrote: "The role of non-military means of achieving political and strategic objectives has increased and, in many cases, exceeded military capabilities in its effectiveness". He suggested using disinformation to achieve Russian political goals. In line with Gerasimov's doctrine, the Arab Spring and the War in South Ossetia have shown that non-military methods of conducting conflict - including information warfare - are more effective than conventional weaponry. Russia sees non-linear actions consisting of military and non-military elements combined in an integrated, comprehensive strategy as the future of warfare (Герасимов, 2013). The methods of informational influence are developed to such an extent that they can enable the state to achieve its strategic goals. 
Russia uses its information tools to advance its foreign policy goals. The RF develops capabilities in three main areas: internally and externally focused media with a substantial online presence, social media and online discussion boards and comment pages as a force multiplier, and language skills to engage with target audiences in their own language. The major propaganda channels are the RT (formerly Russia Today TV) and Sputnik News portal.

Media cooperation between the Russian Federation and the UAE is extensive. Various Russian media outlets have established offices in the UAE, including RIA Novosti and Russia Today. The Emirates News Agency also signed Memoranda of Understanding with Russian media outlets Sputnik and RT in 2018 and 2019, respectively, to facilitate the exchange of information and broadcast content and develop cultural, scientific, and tourism contacts (Diplomatic success, 2019).

\section{Convergence of Strategic Interests of the RF and the UAE}

Relations between the RF and the UAE are developing mainly in the economic and technological spheres and also in political, science, social, and military ones. The UAE seeks to benefit from the RF's growing presence in the Middle East and North Africa, forming a mutually beneficial alliance with the RF for its regional objectives.

The RF and UAE are becoming increasingly influential state actors operating in the region. The RF is dynamically seeking to strengthen its status as a superpower and build strong ties with various actors in the region to achieve political dominance. On the other hand, the UAE, often operating in the shadow of Saudi Arabia's foreign policy, is gradually increasing its regional clout and taking advantage of the RF's rising status. The RF is also interested in an alliance with the UAE because the country is a force for regional stability and secularism and has a large financial capacity that can be used to reinvest in Syria to stabilize the Assad regime. The UAE, despite EU and US sanctions, is increasing its commitment to rebuilding Syria. In doing so, the UAE is supporting the legitimacy of the Assad government in Syria.

Under the slogans of stability and the fight against terrorism, both sides support authoritarian, anti-democratic, and anti-Islamist actors. The RF has acted pragmatically, initially communicating with all parties to the conflict and choosing the most useful ones. These are often reactionary forces that act against democratic but also Islamist movements. The UAE sees these movements as a potential threat to its political status quo (Fenton-Harvey, 2019).

The Syrian civil war has been going on for over ten years, the Libyan civil war for seven years, and the Yemeni one for five years - all with no apparent end in sight. Civil unrest has swept through Algeria, Lebanon, Iraq, and Iran, with more protests likely to come. So the UAE has a vested interest in restoring stability to the region.

Syria: Since the beginning of the Syrian uprising in mid-March 2011, the UAE adopted a relatively ambiguous position regarding events in the country, officially supporting the 
Syrian opposition but maintaining various links with the Assad regime in Damascus (Daher, 2019). The UAE was a member of the international coalition of states opposed to the Damascus regime, called the 'Friends of Syria'. In 2015, the UAE began withdrawing from the Syrian conflict. However, with Russias intervention in Syria and recognizing the high cost and limitations of the previous approach, the UAE was progressively pursuing a rapprochement with the Syrian regime primarily to seek a political role in the future Syria through economic investment in reconstruction plans. In December 2018, it restored diplomatic relations with Syria and legitimized Assad, whom they see as an opponent of Islamism and democracy. In 2018, the UAE supported Assad's return to the Arab League, strengthening its strategic partnership with the Russian Federation. The two countries also share common views on the need to defeat Islamist movements and the importance of protecting Syrian Kurds from Turkish military aggression.

The UAE's increased interest in participating in the reconstruction of Syria is also in line with the needs of the RF. Russia and the UAE view many Islamist groups opposed to Assad as terrorist entities, such as the Muslim Brotherhood and Hayat Tahrir al-Sham (formerly Jabhat al-Nusra) (Ramani, 2019). The UAE is committed to secular governance in Arab countries, which is in line with the interests of the RF. Russia also welcomes the UAE's efforts to invest in the reconstruction of Syria. The RF and the UAE are interested in the reconstruction process, with the UAE providing investment and Russia using its ground presence in Syria to implement reconstruction contracts as hostilities diminish. The UAE's willingness to invest in Syria stems primarily from its desire to persuade Assad to expel Iran from southern Syria.

The UAE's efforts to invest in Syria's reconstruction have been stalled by the tightening of US sanctions on Syria. However, the UAE has denounced the American Caesar Act sanctions as an obstacle for the UAE private sector to coordinate and cooperate with Syria (Tariq, 2019). These restrictions and obstacles make the prospect of Emirati investors returning to Syria more distant. In recent years, however, the UAE has managed to gain some autonomy, allowing for more independent political decisions and foreign policy choices, especially through deepening relations with Washington's rivals, including Russia.

Iran: The geopolitical alignments of the Persian Gulf region are transforming both in bilateral and multilateral formats as "derivative" of a shift in US policy. Iran's priority is to rebuild its economy, ravaged by decades of Western sanctions and isolation (Bhadrakumar, 2021). The RF, maintaining a close relationship with Iran, has been trying to persuade Arab states to distance themselves from the US and seek a direct deal with Iran as part of its concept of a collective security system in the Gulf region. Russia-Emirates' relations have

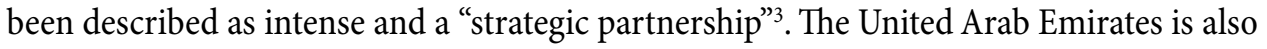

3 H.H. Sheikh Abdullah bin Zayed Al Nahyan, Minister of Foreign Affairs and International Cooperation, stated that the relations between the UAE and Russia are profound and continuous, noting that the two friendly countries enjoy a solid strategic partnership, ABU DHABI, March 9, 2021, WAM. 
Russia's largest trading partner in the Gulf region. By maintaining good relations with Iran and the Arab monarchies, Russia maximizes its influence in the region and increases its value in the eyes of each (Rodkiewicz, 2021). With the US administration of President Biden offering to resume talks with Iran, the UAE's strong economic ties and its existing relationship with Iran make it likely to play a key role in the Gulf's dealings with Tehran (Keynoush Banafsheh, 2021).

The experts interviewed agreed on Russia-Iran relations and differed on their assessment of UAE's relationship with Iran. The major issue pointed by the experts is that Russia and Iran are united around a common goal to reduce the role of the US in the Middle East and thus strive to establish a multipolar world. As for the Iran-UAE's relations, civilian researchers focus more on mutually beneficial trade relations between the two countries. The UAE emerged as Iran's second-biggest trade partner during the billion during the last Iranian year (March 2020-21) (Iran-UAE Relations, 2021).

The military expert, Lieutenant General (Ret.) Andrzej Fałkowski, while agreeing that Russia-Iran efforts aim at diminishing the role of the US in the region, has been careful about multi-folded UAE's diplomatic play. On the one hand, the Emirates have been working with Iran to improve relations to reduce tension, strengthen control over transportation routes in the Persian Gulf and secure their interest in the MENA region and on the other hand, they are advancing its position as a regional security broker continuing strong ties with the USA and establishing relations with Israel ${ }^{4}$.

Foremost, the UAE, in its multi-dimensional approach to regional cooperation in the Middle East, is focused on asserting its independence on the international stage and pursuing interests that are unique to them. This diversity and flexibility in the UAE cooperation with regional actors reflect significant versatility in the UAE diplomatic strategy, which uses soft power ${ }^{5}$ to shape the preferences of others and projecting hard power.

Libya: Since April 2019, the RF and the UAE have supported the self-proclaimed Libyan National Army and its chief Khalifa Belqasim Haftar in the offensive against Tripoli. Haftar opposes a peaceful democratic transition in Libya and uses military and economic aid from both the RF and the UAE in his fight. However, the UAE's strong support for the Libyan National Army and General Khalifa Haftar conflicts with Russia's more cautious balancing strategy in the country and prevents the RF and the UAE from cooperating more deeply to stabilize Libya.

Sudan: Following the Sudanese revolution, on July 4, 2019, the Russian Federation blocked a draft UN resolution condemning the massacre of demonstrators by the Interim Military Council. The RF seeks to secure its position in Africa and benefit from Sudan's natural resources. It also serves the counter-revolutionary aims of the UAE. The UAE has

4 The Abrahamic Accords of August 2020.

5 For example, the UAE has been sending medical equipment to Iran to help Iran fight the COVID-19 pandemic. 
given broad support to the Provisional Military Council, which can count on future support from both sides.

Yemen: One of the RF's policy goals in Yemen and the Middle East is to regain influence in the Persian Gulf, especially in Yemen, through the Gulf Peace Plan (Salami, 2021, pp. 38-39). The RF and the UAE have mutual interests as well as differences in Yemen. In 2019, the UAE provided support to southern Yemeni separatists by conducting airstrikes against Yemeni government forces. The UAE supports the Southern Transitional Council (STC) mainly to consolidate control over key southern logistical locations, including the port of Aden, to increase international maritime trade. The RF supports the territorial integrity of Yemen and maintains good relations with both parties to the conflict in Yemen - the legitimate government and the Houthi. It engages diplomatically with the STC, although it may also choose to support Houthi, given its desire to restore its military base near the strategically important Bab al-Mandab Strait (Russia’s return to Yemen, 2020). A return to the Bab al-Mandab is a Russian strategy that Russia may now seek to pursue while supporting UAE interests in Yemen. The UAE deepened Russian involvement in Yemen by having facilitated meetings between the STC and Putin's special envoy for the Middle East and Africa. As a close partner of both the UAE and Iran, Russia will have a strong position to mediate in Yemen (Katz, 2021).

\section{The Character of Partnership Between the RF and the UAE}

The return of the RF as an influential diplomatic actor on the Arabian Peninsula took US foreign policy by surprise and defied expectations of a permanent rift between the RF and the Gulf over military support for Syrian President Assad. The culmination of Russia's diplomatic efforts on the peninsula was the 2018 ratification of a strategic partnership agreement with the UAE, which is often described as the most trusted US security partner in the Arab world (UAE, Russia forge, 2018).

The relationship between the RF and the UAE is based on a growing synergy between the two countries' objectives and activities in the region despite the occasionally subtle differences. It is particularly evident in Syria. The main driver of cooperation between the RF and the UAE in Syria is increasingly a shared threat perception. In Syria, the UAE position is most closely aligned with that of the RF than any other Gulf Arab state. As Saudi Arabia and Qatar evade formal diplomatic recognition of the Assad government, the UAE is poised to become Russia's most important partner in Syria and the Gulf region.

Ramani argues that the strengthening of relations between the Russian Federation and the UAE is primarily explained by ideological synergy. The leaders of both countries share an aversion to popular revolutions and hostility to grassroots Islamist movements. It is evident in the similar attitudes of the RF and the UAE toward the Sudanese revolution and the Syrian civil war and the prospect of expanding the partnership into a collective security framework for the Gulf (Ramani, 2020, pp. 125-140). In 2009, Sheikh Mohammed 
bin Rashid al-Makhtoum, the ruler of Dubai, stated that democracy was 'not suitable' for the UAE and that the Emirate was satisfied with the 'prosperity and stability' resulting from its political system (Kwong, ${ }^{2009)}$. Both regimes are critical of liberalism, although they distance themselves from the reactionary label and present themselves as the main proponents of progressive political change in the Arab world.

In the absence of international support for progressive change in the region, the authoritarian, anti-democratic leaders that the UAE supports may be more successful. It is likely that the UAE, in approaching Russia politically, will try to move toward a more overt foreign policy, as it did with Yemen.

The RF's actions in the UAE may suggest a move away from the UAE's dependence on the US and a consequent reduction of US influence in the Middle East. Sanctions on Iran and US opposition to the 2015 nuclear deal have increased tensions in the region, threatening the UAE's security, given its geographical proximity along the Arabian Gulf.

However, despite increasing cooperation with the RF and attempts to act independently, the UAE still maintains close ties with the US, whose presence in the Middle East is significant. The UAE's narratives on regional affairs directly influence the US foreign policy stance (Fenton-Harvey ${ }^{2019)}$. The UAE believes that a strategic partnership with Russia will not undercut the alliance with the US.

The partnership between the RF and the UAE translates mainly into diplomatic, economic, trade, educational, cultural, and political relations that are protocooperative. The two countries cooperate in developing mutually beneficial win-win relationships. Russia recognizes its interests in the UAE can be best enhanced through non-military means (Sim, 2018b). The 2018 "Declaration on the strategic partnership between the RF and the UAE" (UAE, Russia forge, 2018) includes dialogue on policy and security issues on key bilateral, regional, and international issues, including in the framework of Russia - Cooperation Council for the Arab States of the Gulf (GCC) Strategic Dialogue, Arab-Russian Cooperation Forum, and other multilateral platforms, cooperation on security and defense, trade and economy, and financial and investment cooperation, bilateral energy interaction, especially on oil and gas issues, cultural and humanitarian, scientific, and technological cooperation. The UAE, more so than any other Gulf state, shares with Russia similar perspectives about conflicts in the Middle East. Their leaders are unequivocal and unapologetic about rooting out all forms and variants of extremism. Russia is seeking greater cooperation to finance Syria's reconstruction, aiming at the UAE, who denounce the American Caesar Act sanctions as an impediment for the UAE's private sector to coordinate and work with Syria (Sim, 2018b). Russia and the UAE are building up stronger economic cooperation. Both are seeking to find a new role not related to mere energy trade. Within the region, the UAE has been at the forefront of modernization and diversification into non-oil sectors, especially trade, real estate, construction, tourism, transportation, and finance.

One of the RF's security strategy goals is ensuring security in a strategically important Gulf area. In the face of common threats, the RF wants to work with the UAE in building 
a more stable collective security architecture for the Gulf. However, the UAE's support for the US's maximum pressure strategy on Iran and isolation of Qatar diverges drastically from the RF's vision of collective security. Russia's commitment to a security concept for the Persian Gulf-based on multilateralism is a sign that it is aware of its great limitations. Czerny (2021) names it a "mirage of great power politics".

\section{Conclusions}

The restoration of global superpower status explains current Russian policy in the MENA region. The Russian Federation seeks to change the global order from one characterized by US hegemony to a multipolar system in which the Russian Federation is one of the main actors. The RF's activity in MENA is a means to achieve this goal, while reversing the dynamics of the Arab Spring or fighting terrorism are secondary objectives (Trenin ${ }^{2018, \text { p. } 21 \text { ). }}$

The UAE's political objectives in the region include preventing the spread of democratic and Islamist forces that could threaten its political status quo. Regionally, the UAE remains active in supporting political allies and countering Islamist and Iranian threats (United Arab Emirates, 2020).

Both the RF and the UAE have interests, seeking to benefit from each other's regional campaigns. Their crucial alliance in a strategic partnership, energy cooperation, regional stability, secularism, and counter-terrorism goes a long way in bridging any differences between them and leading to one of the most important regional partnerships in the Middle East to date (Fenton-Harvey, 2019).

According to EY Geostrategic Business Group, the Middle East remains a geopolitical hotspot, and the politics of the Middle East and North Africa will remain fragmented and unstable in 2021 and beyond. The changing dynamics of geopolitics require governments in the region and global actors to seek a new balance. The engagement of international players in the region is changing. The US continues to maintain and even increase its military presence in the region to contain Iran. China is increasing its diplomatic engagement in the region, cautiously addressing local political and security challenges. The RF presents itself as a regional broker, maintaining its presence in Syria and seeking to expand its influence in the Gulf region (Geostrategic Outlook, 2020, pp. 27-28).

In this context, both Russia and the UAE pursue their foreign policy objectives by increasing their engagement in the region. The RF's commitment is particularly evident in its protocooperative relationship with the UAE. Russia sees the strategic partnership with the UAE as a key success in the resurgence of the RF as a great power in the Middle East. The UAE, with the well-chosen combination of economic and security measures, is also on course to become a regional power.

A continuous development toward greater and fuller cooperation between the two countries, from which both benefits, can be seen in the areas of crisis diplomacy, counterterrorism, trade and economy, social, science, and, foremost, collective security. Shared 
ideas about internal state order, Islamist movements, and more recently, the parameters of escalating relations with Iran, have acted as critical bonds of cohesion between the RF and the UAE. As Russia seeks to become an important actor in Syria, Libya, Yemen, and the Horn of Africa, the importance of bilateral relations will grow proportionately (Ramani, 2020,p. 136). The UAE, more so than any other Gulf state, shares with Russia similar perspectives about conflicts in the Middle East.

Trade and economic relations between the RF and the UAE are developing dynamically. Both countries support innovation, economic diversification, global trade, and foreign investment, including accelerating the transformation of companies toward digitization. They are mutually beneficial, synergistic, and as such could be regarded as protocooperative.

\section{References:}

Bailey, J. (2021). What to Expect from Russia's UAE Supersonic Aircraft Partnership. Simply Flying. Bani Salameh, M.T., \& Mashagbeh, A.A. (2018). The American Russian Rivalry in the Middle East. International Journal of Humanities and Social Science, 8(1).

Bateman, M. (2015). Social and solidarity economy: Beyond the fringe. Zed Books.

Bhadrakumar, M.K. (2021, April 20). Gulf's geopolitics twist and turn in new alignments. Asia Times.

Cikara, M., \& Paluck, E.L. (2013). When Going Along Gets You Nowhere and the Upside of Conflict Behaviours. Social and Personality Psychology Compass, 7.

Czerny, M. (2021). Russia's security mirage in the Gulf. RIDDLE Russia, Kennan Institute.

Daher, J. (2019). The Dynamics and Evolution of UAE-Syria Relations: Between Expectations and Obstacles. European University Institute.

Darczewska, J. (2015). Diabeł tkwi w szczegółach. Wojna informacyjna w świetle Doktryny Wojennej Rosji. Punkt Widzenia, 50.

Duarte de Carvalho, T. (2013). Protocooperative Social Networks. Journal of Communication, 7, 100-115. Fenton-Harvey, J. (2019, November 8). Russia and the UAE Seek Greater Mutual Benefits. Inside Arabia. "Foreign Minister Sergey Lavrov's answers to media questions during a special session of the Valdai International Discussion Club on the Middle East". (2021, March 31). The Ministry of Foreign Affairs of the RF.

"Geostrategic Outlook, Middle East and North Africa, Volatility and the risk of disruption". (2020). EY Global Geostrategic Business Group.

Герасимов, В. (2013, February 26). Ценность науки в предвидении, Новые вызовы требуют переосмыслить формы и способы ведения боевых действи. Военно-промышленный курьер, $8(476)$.

Griffin, R. (2019, October 15). Russia, UAE sign new energy cooperation agreements. Se $P$ Global, Natural Gas $\mid$ Oil.

Huggett, R.J. (2004). Fundamentals of Biogeography. Routledge.

"Iran-UAE Relations". (2021). Financial Tribune.

Issaev, L., \& Kozhanov, N. (2021, February 3). Diversifying relationships: Russian policy toward GCC. International Politics Journal.

Karasik, T. (2017, December 20). Russia's Financial Tactics in the Middle East, Russia in the Middle East. Jamestown Foundation. 
Katz, M.N. (2021, April 9). Russia is friendly with the Houthis in Yemen. But it's complicated. Atlantic Council. Keynoush, B. (2021, February 26). Diplomacy with Iran: Opportunities and Risks for the UAE. The Arab Gulf States Institute in Washington.

Kwong, M. (2009, April 19). “Democracy Wrong Choice for the UAE”, The National (UAE) News. Popescu, N., \& Secrieru, St. (2018). Introduction: Russia’s return to the Middle East. CHAILLOT paper, 146. "Presentation on Russia's Collective Security Concept for the Persian Gulf Region". (2019, July 23). The Ministry of Foreign Affairs of the Russian Federation.

“Российская Концепция коллективной безопасности в зоне Персидского залива”. (2019, July 23). Министерство иностранных дел Российской Федерации.

Ramani, S. (2019, March 11). UAE and Russia Find Common Ground on Syria. The Arab Gulf States Institute. Ramani, S. (2020). Russia and the UAE: An Ideational Partnership. Middle East Policy, 27(1).

Rodin, S. (2019). Cooperation Between Russia and the UAE in the Field of High Technology. Asia and Africa Today, 6.

Rodkiewicz,W. (2021). Aktywizacja polityki Rosji w rejonie Zatoki Perskiej. OSW.

"Russian and CIS relations with the Gulf Region: Current Trends in Political and Economic Dynamics". (2020). Gulf Research Centre.

"Russia’s Putin signs deals worth $\$ 1.3$ bn during UAE visit”. (2019, October 15). Al Jazeera English.

"Russia’s return to Yemen". (2020, March 27). Abaad Studies \& Research Centre.

Salami, M. (2021). Why is Russia Involved in Yemen, Again? Washington Report on Middle East Affairs.

Scaria, S. (2019, October 15). Snapshot: Investment, trade ties between UAE and Russia you should know about.ZAWYA.

Sim, Li-Chen (2018a). Russia's return to the Gulf, External Powers and the Gulf Monarchies. Routledge.

Sim, Li-Chen (2018b, June 7). A Resurgent Russia and a Rising UAE in the Gulf. Rising Powers in Global Governance.

Sim, Li-Chen (2019). Russia and the Gulf States: Pragmatic Energy Partners. Routledge.

Sim, Li-Chen, \& Fulton, J. (2020). Implications of a regional order in flux: Chinese and Russian relations with the United Arab Emirates. Cambridge Review of International Affairs.

Stepanova, E. (2018). Russia and Conflicts in the Middle East: Regionalization and Implications for the West. The International Spectator: Italian Journal of International Affairs.

Tariq, A. (2019, March 9). Emirati-Russian relations are profound, growing steadily: Abdullah bin Zayed. Emirates News Agency.

“Trade: Russia and United Arab Emirates". (2021). The Observatory of Economic Complexity (OEC).

Trenin, D. (2018). Russia's return to the Middle. What drives Russia’s policy in the Middle East? CHAILLOT paper, 146.

Tshikantwa, T.S., Ullah, M.W., He, F., and Yang, G. (2018). Current Trends and Potential Applications of Microbial Interactions for Human Welfare. Frontiers in microbiology, 9(1156).

"UAE buys $\$ 5$ bn of weapons during four-day arms exhibition". (2017, February 23). Middle East Eye.

"UAE is the first Arab destination for Russian investments - economy - local". (2021, June 8). Algulf.net. "UAE, Russia forge strategic partnership". (2018, June 1). Gulf News.

"United Arab Emirates". (2020). The Economists Intelligence Unit.

"Diplomatic success of decades-long relations between UAE and Russia". (2019, October 10). Khaleej Times. Wan, M. (2016). The Asian Infrastructure Investment Bank: The Construction of Power and the Struggle for the East Asian International Order. Palgrave Macmillan.

Wasser, B. (2019). The Limits of Russian Strategy in the Middle East. RAND. 